\title{
Pengaruh Lokasi, Bagi Hasil dan Promosi terhadap Proses Keputusan Nasabah Menabung di PT Panin Dubai Syariah Bank
}

\author{
Erik Rif'ad Hendra Putra ${ }^{1}$ dan Ade Sofyan Mulazid ${ }^{2}$ \\ ${ }^{1}$ Fakultas Ekonomi dan Bisnis, UIN Syarif Hidayatullah Jakarta \\ E-mail:erikrifad95@gmail.com \\ ${ }^{2}$ Fakultas Ekonomi dan Bisnis UIN Syarif Hidayatullah Jakarta \\ E-mail:adesofyanmulazid@uinjkt.ac.id
}

\begin{abstract}
The purpose of this resesarch was to analyze the effect of location, reveneu sharing and promotion simultaneously and partially to decision process to save in product tabungan Flexible in PT Panin Dubai Syariah Bank Jakarta. The sample used in this study were 74 respondents from the customers of PT Panin Dubai Syariah Bank. The analytical method used is multiple linear regression analysis. The data obtained is the primary data that is the result of the respondents' answers to the questionnaire were distributed. These results of this study indicate that there is influence simultaneously on location variable, revenue sharing and promotion towards decision process to save. In the test of determination, there is the influence of a variable 51,9\% location, revenue sharing and promotion to the decision to save. Meanwhile 48,1\%\% (100\% - 51,9\%) were influenced by other variables that not included in this study. The result of this research showed that the location effect partially to the decision process to save, with significant value that is $0,021<0,05$ and $t$ count <t table (2,364 >1,993). Revenue sharing do not effect partially to the decision process to save, with a significant value of 0,503>0,05 and t count $<t$ table $(0,674<1,993)$. Promotion effect partially to the decision process save, with significant value that is 0,000 $\langle 0,05$ and $t$ count $>t$ table $(4,193>1,993)$.
\end{abstract}

Keywords: Location, Revenue Share, Promotion, Decision Process.

\begin{abstract}
Abstrak
Tujuan penelitian ini adalah untuk menganalisis pengaruh lokasi, reveneu sharing dan promosi secara simultan dan parsial terhadap proses keputusan untuk menghemat dalam produk fleksibel di PT Panin Dubai Syariah Bank Jakarta. Sampel yang digunakan dalam penelitian ini adalah 74 responden dari pelanggan PT Panin Dubai Syariah Bank. Metode analisis yang digunakan adalah analisis regresi linier berganda. Data yang diperoleh adalah data primer yang merupakan hasil jawaban responden terhadap kuesioner yang dibagikan. Hasil penelitian ini menunjukkan bahwa ada pengaruh secara simultan terhadap variabel lokasi, pembagian hasil dan promosi terhadap proses keputusan untuk menabung. Dalam uji penentuan, ada pengaruh variabel lokasi 51,9\%, pembagian pendapatan, dan promosi dengan keputusan untuk menyimpan. Sementara 48,1 \%\% (100\% - 51,9\%) dipengaruhi oleh variabel lain yang tidak termasuk dalam penelitian ini. Hasil penelitian menunjukkan bahwa lokasi berpengaruh secara parsial terhadap proses keputusan untuk menyimpan, dengan nilai signifikan yaitu $0,021<0,05$
\end{abstract}


dan thitung 〈t tabel (2,364〉 1,993). Bagi hasil tidak berpengaruh secara parsial terhadap proses keputusan untuk menghemat, dengan nilai signifikan sebesar 0,503>0,05 dan $t$ hitung < t tabel $(0,674<1,993)$. Pengaruh promosi secara parsial terhadap proses keputusan disimpan, dengan nilai signifikan yaitu 0,000 <0,05 dan thitung $t$ tabel $(4,193>$ $1,993)$.

Kata Kunci: Lokasi, Penghasilan, Promosi, Proses Keputusan.

\section{A. Pendahuluan}

Menurut data statistik perbankan syariah di Indonesia, menunjukkan bahwa jaringan kantor bank umum syariah dan unit usaha syariah mengalami perkembangan. Pada tahun 2015 jumlah kantor perbankan syariah yang terdiri atas kantor kas, kantor cabang dan kantor cabang pembantu 2.301 kantor. Sedangkan pada tahun 2017 bulan Januari jumlah kantor perbankan syariah sebanyak 1.966 kantor, pertumbuhan kantor perbankan syariah mengalami penurunan yang cukup besar yakni 335 kantor. Penurunan ini berdampak pada tingkat kepercayaan masyarakat terhadap perbankan syariah yang mulai terkikis dengan pengaruh dari ekonomi dunia yang terus menerus berubah.

PT Panin Dubai Syariah Bank saat ini memiliki 22 kantor cabang yang tersebar di seluruh Indonesia, 4 di antaranya berada di Jakarta. Lokasi yang strategis merupakan faktor utama dari berkembangnya suatu bank syariah. Lokasi merupakan hal yang penting untuk dipertimbangkan dalam menarik nasabah untuk menggunakan produk dan jasa yang dimiliki oleh PT Panin Dubai Syariah Bank. Menurut Lupiyoadi (2001: 61) mendefinisikan lokasi adalah tempat di mana perusahaan harus bermarkas melakukan operasi. Penentuan lokasi suatu cabang bank merupakan salah satu kebijakan yang sangat penting. Bank yang terletak dalam lokasi yang strategis sangat memudahkan nasabah dalam berurusan dengan bank.

Selain melihat lokasi, nasabah juga mempertimbangkan beberapa hal yang perlu menjadi perhatian guna menjamin tercapainya sasaran pengembangan perbankan syariah. Beberapa di antaranya telah teridentifikasi, yaitu peraturan perundang-undangan yang sesuai dengan karakteristik usaha perbankan syariah sangat diperlukan. Pertumbuhan jaringan kantor yang dapat memenuhi kebutuhan masyarakat yang semakin meningkat terhadap jasa perbankan syariah, tersedianya infrastruktur dan lembaga pendukung yang dapat mendorong perkembangan perbankan syariah yang sehat dan istiqomah (teguh) menjalankan 
prinsip syariah. Meningkatkan efisiensi operasi, mutu pelayanan dan daya saing perbankan syariah nasional, mendorong perkembangan pembiayaan bagi hasil dalam proporsi yang memadai dalam portofolio pembiayaan bank syariah dan terciptanya bank syariah yang memiliki kompetensi, profesional dan dapat memenuhi standar yang ditetapkan secara internasional (Hamidi, 2003: 11).

Selain dilihat dari lokasi dan keuntungan yang dimiliki oleh PT Bank Panin Dubai Syariah yang dapat mempengaruhi nasabah untuk menggunakan produk atau jasa, promosi dibutuhkan guna meyakinkan nasabah menggunakan produk atau jasa. Promosi menyebabkan orang yang sebelumnya tidak tertarik untuk membeli suatu produk atau jasa, akan menjadi tertarik dan mencoba produk atau jasa sehingga konsumen melakukan pembelian. Tanpa promosi jangan diharapkan nasabah dapat mengenal bank. Oleh karena itu, promosi merupakan sarana yang paling ampuh untuk menarik dan mempertahankan nasabahnya. Salah satu tujuan promosi bank adalah menginformasikan segala jenis produk yang ditawarkan dan berusaha menarik calon nasabah (Kasmir, 2005:175).
Berdasarkan uraian di atas, maka penulis memandang penting untuk melakukan penelitian lebih lanjut.

Tujuan dari penelitian ini adalah:

a. Untuk menganalisis pengaruh secara parsial lokasi terhadap proses keputusan nasabah menabung.

b. Untuk menganalisis pengaruh secara parsial bagi hasil terhadap proses keputusan nasabah menabung.

c. Untuk menganalisis pengaruh secara parsial promosi terhadap proses keputusan nasabah menabung.

d. Untuk menganalisis pengaruh secara simultan tingkat lokasi, bagi hasil dan promosi terhadap proses keputusan nasabah menabung.

\section{B. Kajian Teori}

\section{Manajemen Pemasaran}

Menurut Kotler dan Keller (2008: 6) pemasaran adalah seperangkat proses untuk menciptakan, mengomunikasikan dan menyerahkan nilai kepada pelanggan dan mengelola hubungan pelanggan dengan cara yang menguntungkan organisasi dan para pemilik sahamnya.

Secara umum, pengertian pemasaran bank adalah suatu proses untuk menciptakan dan mempertukarkan produk atau jasa bank yang ditujukan untuk memenuhi kebutuhan dan 
keinginan nasabah dengan cara memberikan kepuasan (Kasmir, 2005: 63).

\section{Pengertian Lokasi}

Menurut Kasmir (2013: 145), bank adalah tempat dimana diperjualbelikan produk cabang bank dan pusat pengedalian perbankan. Dalam bisnis jasa bank, penentuan lokasi dimana bank akan beroperasi merupakan salah satu faktor yang penting untuk kegiatan pemasaran bank. Penentuan lokasi mempunyai pengaruh yang cukup signifikan dalam aktivitas menghimpun pengaruh yang cukup signifikan dalam aktivitas menghimpun dana masyarakat serta menyalurkan pembiayaan kembali kepada masyarakat.

\section{Pengertian Bagi Hasil}

Dalam perekonomian modern pada dasarnya bank merupakan lembaga penyalur dana antara pihak yang berlebihan dengan pihak yang kekurangan dana. Dalam kegiatan ini disebut "intermediary". Tugas bank adalah menerima simpanan dan memberi pinjaman. Bank adalah lembaga yang bergerak dalam "usaha dagang." Oleh karena itu, keuntungan merupakan sesuatu yang penting dalam usahanya (Abdullah, 2006:59).
Sebagai alternatif sistem bunga dalam ekonomi konvensional, ekonomi Islam menawarkan sistem bagi hasil (profit and loss sharing) ketika pemilik modal (surplus spending unit) bekerjasama dengan pengusaha (deficit spending unit) untuk melakukan kegiatan usaha (Ascarya, 2011: 26).

\section{Pengertian Promosi}

Promosi merupakan salah satu variabel dalam bauran pemasaran yang sangat penting dilaksanakan oleh perusahaan dalam memasarkan produk. Kegiatan promosi bukan saja berfungsi sebagai alat komunikasi antara perusahaan dengan konsumen, melainkan juga sebagai alat untuk memengaruhi konsumen dalam kegiatan pembelian atau penggunaan produk sesuai dengan kebutuhan dan keinginannya (Sunyoto, 2012: 154).

Menurut Kasmir (2005: 175) promosi merupakan kegiatan marketing mix yang terakhir. Kegiatan ini merupakan kegiatan yang sama pentingnya dengan kegiatan produk, harga dan lokasi. Dalam kegiatan ini setiap bank berusaha untuk mempromosikan seluruh produk dan jasa yang dimilikinya baik langsung maupun tidak langsung. 
C. Metodologi Penelitian

\section{Hipotesis}

Hipotesis merupakan jawaban sementara terhadap masalah penelitian, di mana rumusan penelitian telah dinyatakan dalam bentuk kalimat pertanyaan (Sugiyono, 2010:84). Hipotesis yang diajukan sebagai jawaban sementara terhadap permsasalahan yang diajukan dalam penelitian ini adalah sebagai berikut:

a. Ho : $\beta 1: \beta 2: \beta 3=0$, tidak terdapat pengaruh secara simultan antara lokasi, bagi hasil dan promosi terhadap proses keputusan nasabah menabung pada PT Panin Dubai Syariah Bank.

$\mathrm{Ha}: \beta 1: \beta 2: \beta 3 \neq 0$, terdapat pengaruh secara simultan antara lokasi, bagi hasil dan promosi terhadap proses keputusan nasabah menabung pada PT Panin Dubai Syariah Bank.

b. Hol : $\beta 1=0$, tidak terdapat pengaruh antara lokasi terhadap proses keputusan nasabah menabung pada PT Panin Dubai Syariah Bank.

Hal : $\beta 1 \neq 0$, terdapat pengaruh antara lokasi terhadap proses keputusan nasabah menabung pada PT Panin Dubai Syariah Bank.

c. Ho2 : $\beta 2=0$, tidak terdapat pengaruh antara bagi hasil terhadap proses keputusan nasabah menabung pada PT Panin Dubai Syariah Bank.

Ha2 : $\beta 2 \neq 0$, terdapat pengaruh antara bagi hasil terhadap proses keputusan nasabah menabung pada PT Panin Dubai Syariah Bank.

d. Ho3 : $\beta 3=0$, tidak terdapat pengaruh antara promosi terhadap proses keputusan nasabah menabung pada PT Panin Dubai Syariah Bank.

Ha3 : $\beta 3 \neq 0$, terdapat pengaruh antara promosi terhadap proses keputusan nasabah menabung pada PT Panin Dubai Syariah Bank.

\section{Jenis Penelitian}

Pendekatan yang digunakan dalam penelitian ini, yaitu penelitian kuantitatif atau statistik dengan tujuan menguji hipotesis yang telah ditetapkan. Penelitian ini menggunakan medote penelitian kuantitatif. Metode ini disebut metode kuantitatif karena data penelitian berupa angka-angka dan analisis menggunakan statistik (Sugiyono, 2010:13). Terdapat dua macam statistik yang digunakan untuk analisis data dalam penelitian, yaitu statistik deskriptif dan statistik inferensial (Sugiyono, 2010:254). Pada penelitian ini, penulis menggunakan statistik deskriptif. Statistik deskriptif adalah statistik yang digunakan untuk menganalisis data dengan cara 
mendiskripsikan atau menggambarkan data yang telah terkumpul sebagaimana adanya tanpa bermaksud membuat kesimpulan yang berlaku untuk umum atau generalisasi (Sugiyono, 2010:254255).

\section{Populasi dan Sampel}

Populasi adalah wilayah generalisasi yang terdiri atas objek atau subjek yang mempunyai kualitas dan karakteristik tertentu yang ditetapkan oleh peneliti untuk dipelajari dan kemudian ditarik kesimpulannya (Sugiyono, 2010: 135). Jadi populasi bukan hanya orang, tetapi juga objek dan benda-benda alam yang lain. Populasi juga bukan sekedar jumlah yang ada pada objek subjek yang dipelajari, tetapi meliputi seluruh karakteristik atau sifat yang dimiliki oleh subjek atau objek itu. Populasi dalam penelitian ini adalah nasabah aktif PT Panin Dubai Syariah Bank yang membuka tabungan pas flexible di Jakarta. Sampel yang digunakan pada penelitian ini adalah 74 responden.

\section{Metode Pengambilan Data}

Dalam penelitian ini metode pengumpulan data yang digunakan adalah metode kuesioner. Sedangkan menurut Sugiyono (2010: 142) kuesioner adalah teknik pengumpulan data yang dilakukan dengan cara memberi seperangkat pertanyaan atau pernyataan tertulis kepada responden untuk dijawab.

\section{Metode Analisis Data}

Analisis data dilakukan dengan kuantitatif, kemudian analisis yang dilakukan terhadap data antara lain uji statistik deskriptif, uji validasi, uji reliabilitas, uji asumsi klasik, uji parsial dan uji simultan, analisis regresi linier berganda pada variabel lokasi (Xl), bagi hasil (X2) dan promosi (X3) dan proses keputusan nasabah (Yl).

a. Statistik Deskriptif

Metode statistik deskriptif dipilih untuk menjelaskan demografi responden dan deskripsi variabel penelitian. Statiistik deskriptif memberikan gambaran atau deskripsi suatu data yang dilihat dari nilai ratarata (mean), standar deviasi, maksimum, minimum, sum, rage, kurtois dan skewness (kemencengan distribusi) (Ghozali, 2003:19).

b. Uji Kualitas Data

\section{Uji Validitas}

Pengujian validitas pada penelitian ini dilakukan dengan membandingkan nilai $\mathrm{r}$ hitung dengan $r$ tabel untuk degree of freedom $(\mathrm{df})=\mathrm{n}-2$, dalam hal ini $\mathrm{n}$ adalah jumlah sampel. Jika $r$ hitung 
lebih besar dari $\mathrm{r}$ tabel dan nilai positif maka pertanyaan atau indikator tersebut dinyatakan valid, tetapi jika $\mathrm{r}$ hitung lebih kecil dari pada $r$ tabel maka pertanyaan atau indikator tersebut tidak valid (Ghozali, 2016: 52-53). Kriteria yang digunakan dalam menetukan valid tidaknya pertanyaan atau penyataan yang digunakan dalam penelitian ini adalah:

a) Alpha $=0,05$ (signifikasi alpha $5 \%)$

b) Jumlah responden sebanyak 30 responden untuk try out (uji coba)

c) Dari 30 responden untuk menemukan $\mathrm{r}$ tabelnya adalah $\mathrm{n}$ $2,30-2=28 \mathrm{r}$ tabel dari 28 adalah $=0,361$

2. Uji Reliabilitas

Menurut Ghozali (2013: 47-48) uji reliabilitas adalah alat untuk mengukur suatu kuesioner yang merupakan indikator dari variabel atau konstruk. Suatu kuesioner dikatakan reliabel atau handal jika jawaban seseorang terhadap pertanyaan adalah konsisten atau stabil dari waktu ke waktu. Pengukuran reliabilitas penelitian ini dilakukan dengan rumus Cronback Alpha $(\alpha)$, suatu kontruk dikatakan atau variabel dikatakan reliabel jika hasil uji reliabilitas memberikan nilai Cronback Alpha > Alpha 0,70.

c. Uji Asumsi Kalsik

1. Uji Multikolinieritas

Menurut Ghozali (2013: 105-106) uji multikoliniertas digunakan untuk menguji apakan pada model regersi ditemukan adanya korelasi di antara variabel independen. Model regresi yang baik seharusnya tidak terjadi korelasi diantara variabel independen. Jika variabel independen saling berkolerasi, maka variabel-variabel tidak ortognal atau nilai korelasi antar sesama variabel independen sama dengan nol, kemudian untuk mengetahuai ada tidaknya multikolinieritas data dilihat dari nilai tolerance dan lawanya, variance inflation factor (VIF).

2. Uji Heteroskedastisitas

Uji ini dilakukan untuk menguji apakah dalam model regresi terdapat ketidaksamaan variance dari residual satu ke pengamatan lain. Jika variance dari satu pengamatan kepengamatan lain tetap, maka disebut homokedasitas dan jika berbeda disebut heteroskedastisitas. Kemudian untuk 
mendeteksi dapat dilihat dengan uji park, di mana apabila variabel independen signifikan secara statistik. Hal ini menunjukkan bahwa dalam data model empiris terdapat heterokesdastisitas. Sebaliknya jika variabel independen tidak ada yang signifikan, maka dapat disimpulkan tidak terdapat heteroskedastisitas (Ghozali, 2013: 141).

3. Uji Normalitas

Uji ini bertujuan untuk menguji apakah dalam model regresi, variabel penganggu atau residual memiliki distribusi normal. Uji normalitas bisa dilihat dengan uji statistik non-parametrik komogrov smirnov (K-S). data dikatakan menyebar normal jika probabilitas atau p > 0,05 (Ghozali, 2013: 164165).

\section{Analisis Regresi Berganda}

Menurut Ghozali (2013: 95) analisis regresi adalah studi mengenai ketergantungan variabel dependen (terikat) dengan satu atau lebih variabel independen (variabel bebas). Dengan tujuan untuk mengestimasi atau memprediksi rata-rata populasi atau nilai ratarata variabel dependen berdasarkan nilai variabel independen yang diketahui. Analisis ini dimaksudkan untuk mengetahui apakah pengaruh antara promosi, pengetahuan nasabah, kualitas produk dan kualitas promosi terhadap proses keputusan nasabah menggunakan produk tabungan.

5. Koefisien Determinasi $\left(\mathrm{R}^{2}\right)$

Koefisien determinan atau $\mathrm{R}^{2}$ mengukur seberapa jauh kemampuan model dalam menerangkan variasi variabel dependen. Nilai koefisien determinasi adalah antara nol dan satu. Nilai $\mathrm{R}^{2}$ yang kecil berarti kemampuan variabel-variabel independen dalam menjelaskan variasi variabel dependen amat terbatas. Nilai mendekati satu berarti variabel-variabel memberikan hamper semua informasi yang dibutuhkan untuk memprediksi variasi variabel dependen (Ghozali, 2013: 97).

\section{Hasil Analisis dan Pembahasan}

\section{Karakteristik Responden}

Penelitian ini menggunakan data primer yang dikumpulkan dengan cara menyebarkan kuesioner kepada responden yaitu nasabah Bank Panin Syariah Jakarta. Jumlah data yang berhasil didapatkan sebanyak 74 responden. 
Berikut ini merupakan penjabaran sebanyak 25 orang atau dalam presentase responden tersebut.

Tabel 1. Jenis Kelamin Responden sebesar $33,8 \%$.

Tabel 3. Profesi Responden

\begin{tabular}{|rr|r|r|}
\hline \multicolumn{1}{|l|}{ Valid } & & Frequency & Percent \\
\cline { 2 - 3 } & Pria & 45 & $60,8 \%$ \\
\cline { 2 - 3 } & Wanita & 29 & $39,2 \%$ \\
\cline { 2 - 3 } & Total & 74 & $100 \%$ \\
\hline
\end{tabular}

\begin{tabular}{|cl|r|r|}
\hline \multirow{3}{*}{ Valid } & & Frequency & Percent \\
\cline { 3 - 3 } & Manager & 4 & $5,4 \%$ \\
\cline { 2 - 3 } & Karyawan & 58 & $78,4 \%$ \\
\cline { 2 - 3 } & Wiraswasta & 8 & $10,8 \%$ \\
\cline { 2 - 3 } & Mahasiswa & 4 & $5,4 \%$ \\
\cline { 2 - 3 } & Total & 74 & $100 \%$ \\
\hline
\end{tabular}

Berdasarkan keterangan pada tabel di atas, dapat diketahui jenis kelamin responden nasabah Bank Panin Syariah mayoritas adalah pria dengan jumlah 45 dari 74 responden dengan presentase sebesar $60,8 \%$ pria dan $39,2 \%$ wanita.

Tabel 2. Usia Responden

\begin{tabular}{|c|c|c|c|}
\hline & Frequency & Percent \\
\hline \multirow[t]{5}{*}{ Valid } & \multirow{5}{*}{$\begin{array}{l}17-20 \\
21-25 \\
26-30 \\
>30 \\
\text { Total }\end{array}$} & 2 & $2,7 \%$ \\
\hline & & 14 & $18,9 \%$ \\
\hline & & 33 & $44,6 \%$ \\
\hline & & 25 & $33,8 \%$ \\
\hline & & 74 & $100 \%$ \\
\hline
\end{tabular}

Berdasarkan keterangan pada tabel di atas, dapat diketahui bahwa yang memiliki umur 17-20 tahun sebanyak 2 orang atau dalam presentase sebesar 2,7\%. Jumlah responden yang berusia 21-25 sebanyak 14 orang atau dalam presentase sebesar 18,9\%. Jumlah reponden yang berusia 26-30 sebanyak 33 orang atau dalam presentase sebesar 44,6\%. Jumlah responden yang berusia di atas 30 (>30)

di atas, dapat diketahuan bahwa jumlah responden mahasiswa sebanyak 4 responden dengan presentase sebesar $5,4 \%$. Sedangkan responden dengan pekerjaan sebagai karyawan sebanyak 58 responden dengan presentase sebesar $78,4 \%$. Responden dengan pekerjaan sebagai wiraswasta sebanyak 8 responden dengan presentase sebesar 10,8\%. Responden dengan pekerjaan sebagai manager sebanyak 4 responden dengan presentase sebesar 5,4\%.

Tabel 4. Jumlah Responden

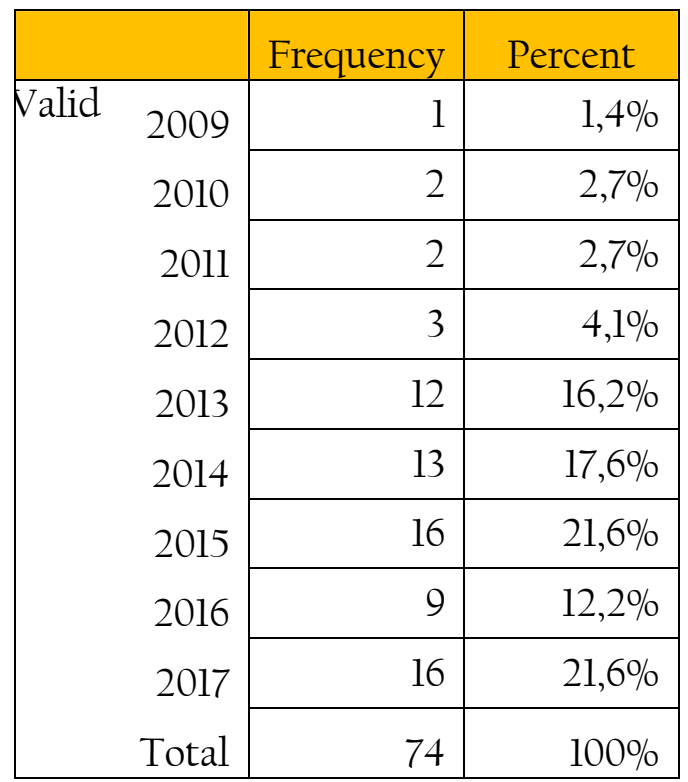


Berdasarkan tabel di atas, maka dapat diketahui bahwa jumlah responden yang membuka tabungan tahun 2009 sebanyak 1 orang dengaan presentase sebesar 1,4\%. Responden yang membuka tahun 2010 sebanyak 2 orang dengan presentase sebesar 2,7\%. Responden yang membuka tahun 2011 sebanyak 2 orang dengan presentase sebesar 2,7\%. Responden yang membuka tahun 2012 sebanyak 3 orang dengan presentase sebesar 24,1\%. Responden yang membuka tahun 2013 sebanyak 12 orang dengan presentase sebesar 16,2\%. Responden yang membuka pada tahun 2014 sebanyak 13 orang dengan presentase sebesar 17,6\%. Responden yang membuka pada tahun 2015 sebanyak 16 orang dengan presentase sebesar $21,6 \%$. Responden yang membuka pada tahun 2016 sebanyak 9 orang dengan presentase sebesar 12,2\%. Responden yang membuka pada tahun 2017 sebanyak 16 orang dengan presentase sebesar 21,6\%.

\section{Uji Validitas dan Reliabilitas}

Uji validitas akan menguji masingmasing dari variabel yang akan digunakan dalam penelitian ini. Berikut ini adalah uji validitas dari variabel lokasi, bagi hasil, promosi dan keputusan dengan sempel yang dimiliki 30 responden.
Tabel 5. Uji Validitas dan

\section{Reliabilitas}

\begin{tabular}{|c|c|c|c|}
\hline Pernyataan & r tabel & $\begin{array}{c}\mathrm{r} \\
\text { hitung }\end{array}$ & Ket. \\
\hline Ll & 0,361 & 0,585 & Valid \\
\hline L2 & 0,361 & 0,714 & Valid \\
\hline L3 & 0,361 & 0,767 & Valid \\
\hline L4 & 0,361 & 0,729 & Valid \\
\hline L5 & 0,361 & 0,597 & Valid \\
\hline L6 & 0,361 & 0,560 & Valid \\
\hline B1 & 0,361 & 0,827 & Valid \\
\hline B2 & 0,361 & 0,849 & Valid \\
\hline B3 & 0,361 & 0,680 & Valid \\
\hline B4 & 0,361 & 0,850 & Valid \\
\hline B5 & 0,361 & 0,361 & Valid \\
\hline P1 & 0,361 & 0,869 & Valid \\
\hline P2 & 0,361 & 0,650 & Valid \\
\hline P3 & 0,361 & 0,811 & Valid \\
\hline P4 & 0,361 & 0,501 & Valid \\
\hline P5 & 0,361 & 0,762 & Valid \\
\hline P6 & 0,361 & 0,720 & Valid \\
\hline P7 & 0,361 & 0,451 & Valid \\
\hline K1 & 0,361 & 0,618 & Valid \\
\hline K2 & 0,361 & 0,698 & Valid \\
\hline K3 & 0,361 & 0,685 & Valid \\
\hline K4 & 0,361 & 0,628 & Valid \\
\hline
\end{tabular}

Berdasarkan tabel di atas, menunjukan bahwa butir pertanyaan dari masing-masing varibel memiliki kriteria yang valid untuk semua item. 
Berdasarkan kriteria yaitu 0,783 yang berarti data pada variabel signifikan dimana dapat dikatakan bagi hasil bersifat reliabel.

valid, apabila nilai signifikan lebih

Tabel 8. Cronbach's Alpha Dari

kecil dari 0,05 dan rhitung lebih

Variabel Promosi

besar dari rtabel yaitu 0,361. Pene

mendapatkan nilai rtabel 0,361 ya Variabel

dengan menggunakan rumus $\mathrm{df}$

2, dimana $\mathrm{n}$ adalah 30 , jadi $\mathrm{df}=30$ - Promosi

Cronbach's Alpha

$\mathrm{N}$ of Items

Ket.

$=28$, maka nilai yang didapat rtabel

yaitu 0,361 .

Tabel 6.

Cronbach's Alpha Darin Variabel

\begin{tabular}{|c|c|c|c|}
\hline Variabel & $\begin{array}{c}\text { Cronbach's } \\
\text { Alpha }\end{array}$ & $\begin{array}{c}\text { N of } \\
\text { Items }\end{array}$ & Ket. \\
\hline Lokasi & 0,762 & 7 & Reliabel \\
\hline
\end{tabular}

Lokasi

Berdasarkan tabel di atas, bahwa nilai Cronbach's Alpha dari variabel lokasi menunjukkan bahwa nilai $>0,70$ yaitu 0,762 yang berarti data pada variabel lokasi bersifat reliabel.

Tabel 7. Cronbach's Alpha Dari Variabel Bagi Hasil

Berdasarkan tabel di atas, bahwa nilai Cronbach's Alpha dari variabel bagi hasil menunjukkan bahwa nilai >0,70
Berdasarkan tabel di atas, bahwa nilai Cronbach's Alpha dari variabel promosi menunjukkan bahwa nilai $>0,70$ yaitu 0,771 yang berarti data pada variabel promosi bersifat reliabel.

\section{Tabel 9. Cronbach's Alpha Dari}

Variabel Proses Keputusan

\begin{tabular}{|c|c|c|c|}
\hline Variabel & $\begin{array}{c}\text { Cronbach's } \\
\text { Alpha }\end{array}$ & $\begin{array}{c}\text { N of } \\
\text { Items }\end{array}$ & Ket. \\
\hline $\begin{array}{c}\text { Prose } \\
\text { Keputusa } \\
\mathrm{n}\end{array}$ & 0,748 & 5 & Reliabel \\
\hline
\end{tabular}

Berdasarkan table di atas, bahwa nilai Cronbach's Alpha dari variabel proses keputusan menunjukkan bahwa

\begin{tabular}{|c|c|c|c|}
\hline Variabel & $\begin{array}{c}\text { Cronbach's } \\
\text { Alpha }\end{array}$ & $\begin{array}{c}\text { N of } \\
\text { Items }\end{array}$ & Ket. \\
\hline $\begin{array}{c}\text { Bagi } \\
\text { Hasil }\end{array}$ & 0,783 & 6 & Reliabel \\
\hline
\end{tabular}

pada variabel proses keputusan bersifat reliabel. 
3. Uji Asumsi Klasik

\section{a. Uji Multikolonieritas}

Uji multikolonieritas bertujuan untuk menguji apakah model regresi ditemukan adanya korelasi antara variabel bebas (independent). Untuk menguji multikolonieritas dengan cara melihat nilai VIF masing-masing variabel independen, jika nilai VIF<10, maka dapat disimpulkan data bebas dari gejala multikolonieritas (Ghozali, 2011: 105).

Tabel 10. Uji Multikolonieritas

\begin{tabular}{|l|l|c|c|}
\hline \multicolumn{3}{|c|}{ Coefficients $^{\mathrm{a}}$} \\
\hline \multirow{2}{*}{\multicolumn{2}{|c|}{}} & $\begin{array}{r}\text { Collinearity } \\
\text { Statistics }\end{array}$ \\
\cline { 2 - 4 } Model & Tolerance & VIF \\
\hline 1 & Lokasi & 0,581 & 1,721 \\
\cline { 2 - 4 } & $\begin{array}{l}\text { Bagi } \\
\text { Hasil }\end{array}$ & 0,572 & 1,747 \\
\cline { 2 - 4 } & Promosi & 0,604 & 1,655 \\
\hline \multicolumn{3}{|l|}{$\begin{array}{l}\text { c. Dependent Variabel: Proses } \\
\text { Keputusan }\end{array}$} \\
\hline
\end{tabular}

Berdasarkan tabel hasil perhitungan nilai tolerance menunjukkan tidak ada varibel independen yang memiliki nilai tolerance lebih besar dari 0,10 (>0,10), yaitu 0,581 untuk nilai variabel lokasi, 0,572 untuk nilai variabel bagi hasil dan 0,604 untuk nilai variabel promosi.
Hasil perhitungan VIF juga menunjukkan hal yang sama, yaitu tidak ada satu pun variabel independen yang memiliki nilai VIF kurang dari $10(<10)$, yaitu 1,721 untuk nilai variabel lokasi, 1,747 untuk nilai variabel bagi hasil dan 1,655 untuk nilai promosi. Dari hasil tersebut dapat disimpulkan bahwa tidak terjadi multikolinieritas dalam model regresi.

\section{b. Uji Heterokedastisitas}

Uji heteroskedastisitas bertujuan untuk menguji apakah dalam model regresi terjadi ketidaksamaan varian dari residual satu pengamatan ke pengamatan yang lain. Uji heteroskedastisitas dapat dilihat mengggunakan grafik plot antara nilai prediksi variabel terikat dengan residu, jika grafik plot menunjukkan suatu pola titik yang bergelombang atau melebar kemudia menyempit maka dapat disimpulkan bahwa telah terjadi heteroskedastisitas, tetapi jika grafik plot tidak membentuk pola yang jelas, maka tidak terjadi heteroskedastisitas (Ghozali, 2011: 139). 
Grafik 1. Uji Heterokedastisitas

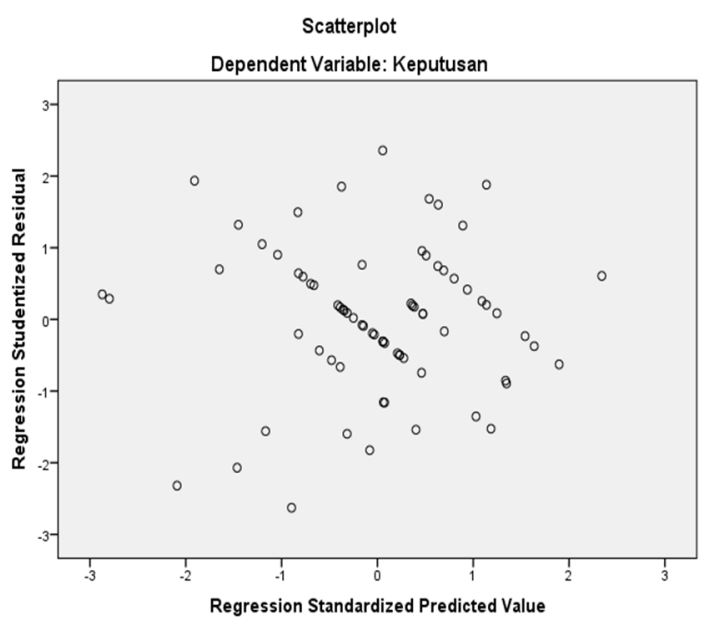

Dari grafik scatterplot di atas, terlihat bahwa titik-titik menyebar secara acak dan tersebar baik di atas di bawah angka nol pada sumbu Y. Hal ini dapat disimpulkan bahwa tidak terjadi heterokedastisitas pada model regresi, sehingga model regresi layak dipakai untuk memprediksi keputusan berdasarkan variabel lokasi, bagi hasil dan promosi.

\section{c. Uji Normalitas}

\section{Grafik 2. Uji Normalitas}

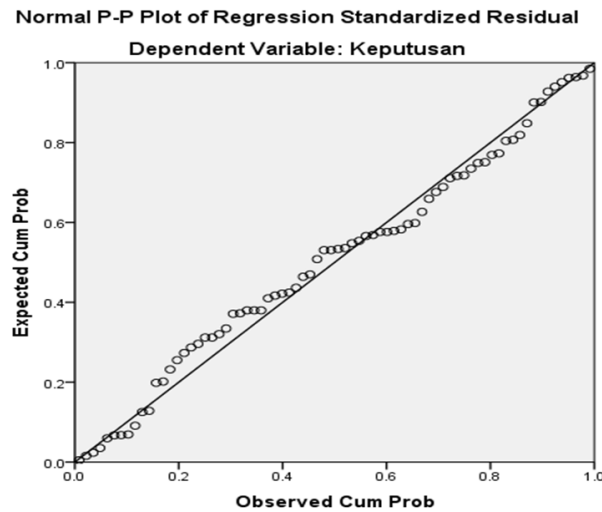

Hasil pengujian dengan memperhatikan grafik p-p terlihat bahwa data-data menyebar disekitas garis diagonal dan mengikuti arah garis diagonal sehingga dapat dinyatakan normal.

\section{d. Uji Kolmogorov-Smirnov}

Untuk menguji apakah data berdistribusi normal atau tidak dilakukan uji statistik Kolmogorov-Smirnov Test. Residual berdistribusi normal jika memiliki nilai signifikansi > 0.05 (Ghozali, 2011:160).

Tabel 11. Uji Kolmogorov-Smirnov

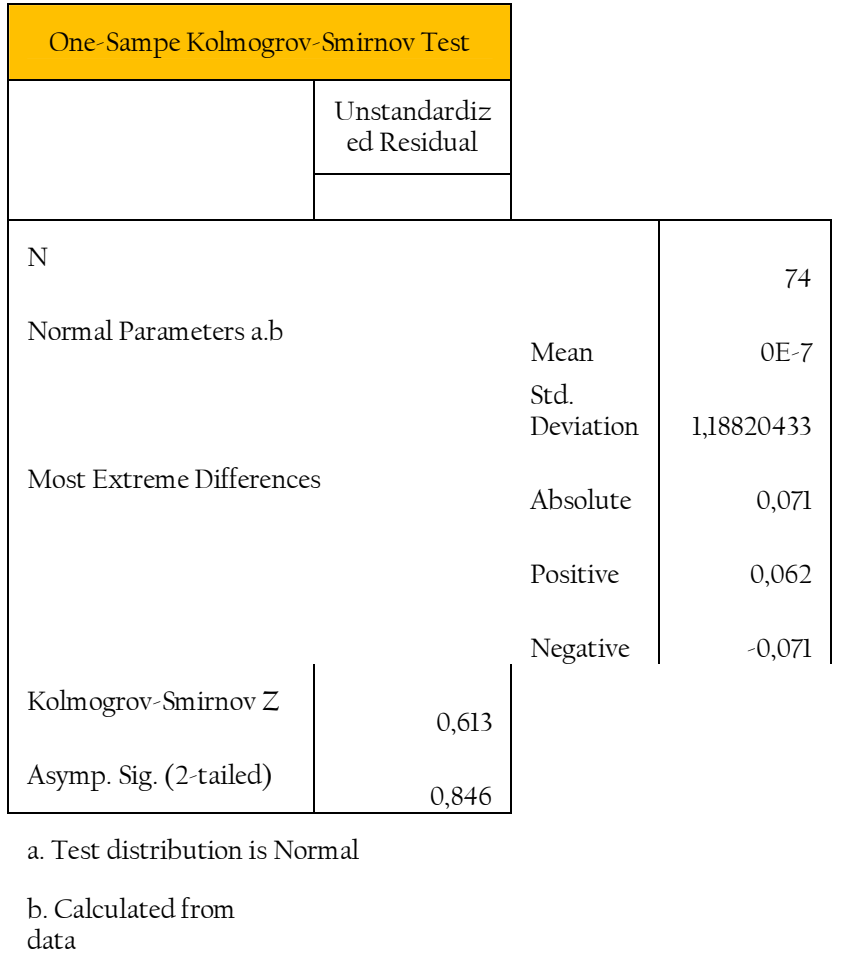


Hasil pengujian menunjukkan bahwa tingkat signifikansi residual (2tailed) sebesar 0,846 yang lebih besar dari 0,05 sehingga dapat disimpulkan bahwa model penelitian memiliki distribusi data normal.

\section{e. Analisis Regresi Berganda}

Tabel 12. Analisis Regresi Berganda

\begin{tabular}{|r|c|c|}
\hline \multicolumn{2}{|c|}{ Coefficients $^{\mathrm{a}}$} \\
\hline \multirow{2}{*}{ Variabel } & \multicolumn{2}{|c|}{$\begin{array}{c}\text { Unstandardized } \\
\text { Coefficients }\end{array}$} \\
\cline { 2 - 3 } (Constant) & 4,635 & 1,452 \\
\cline { 2 - 3 } Lokasi & 0,140 & 0,059 \\
\cline { 2 - 3 } Bagi Hasil & 0,061 & 0,090 \\
\cline { 2 - 3 } Promosi & 0,256 & 0,052 \\
\hline
\end{tabular}

a. Dependent Variabel: Proses Keputusan

Dari persaman regresi berganda tersebut menunjukkan bahwa variabel bagi hasil adalah variabel yang paling mempengaruhi secara signifikan yaitu sebesar 0,256 atau 25,6\%.

\section{f. Uji F}

\section{Tabel 13. Uji F}

Maka model regresi dapat digunakan untuk memprediksi keputusan nasabah untuk menabung atau dapat dikatakan bahwa $\mathrm{Ha}$ diterima yaitu lokasi, bagi hasi dan promosi berpengaruh secara simultan terhadapat keputusan nasabah menjadi nasabah di Bank Panin Dubai Syariah Bank.

\begin{tabular}{|l|l|r|r|r|r|c|}
\hline \multicolumn{2}{|c|}{} & \multicolumn{1}{|c|}{$\begin{array}{l}\text { Sum of } \\
\text { Squares }\end{array}$} & \multicolumn{1}{c|}{ df } & \multicolumn{1}{c|}{$\begin{array}{c}\text { Mean } \\
\text { Square }\end{array}$} & f & Sig. \\
\hline \multirow{2}{*}{1} & Regression & 120,396 & 3 & 40,132 & 27,257 & $0,000^{\mathrm{b}}$ \\
\cline { 2 - 8 } & Residual & 103,064 & 70 & 1,472 & & \\
\cline { 2 - 8 } & Total & 223,459 & 73 & & & \\
\hline
\end{tabular}

a. Dependent Variabel: Proses Keputusan

b. Predictors: (Constant), Promosi, Lokasi, Bagi Hasil

\section{g. Uji t}

Tabel 14. Uji t

\begin{tabular}{|c|c|c|c|c|c|}
\hline \multirow[b]{3}{*}{ Variabel } & \multicolumn{4}{|c|}{ Coefficients $^{\mathrm{a}}$} & \multirow[b]{3}{*}{ Sig. } \\
\hline & \multicolumn{2}{|c|}{$\begin{array}{l}\text { Unstandardized } \\
\text { Coefficients }\end{array}$} & \multirow{2}{*}{$\begin{array}{c}\begin{array}{c}\text { Std. } \\
\text { Coefficie } \\
\text { nts }\end{array} \\
\text { Beta } \\
\end{array}$} & \multirow[b]{2}{*}{$\mathrm{t}$} & \\
\hline & B & $\begin{array}{l}\text { Std. } \\
\text { Error }\end{array}$ & & & \\
\hline (Constant) & 4,635 & 1,452 & & 3,192 & 0.002 \\
\hline Lokasi & 0,140 & 0,059 & 0,252 & 2,364 & 0,021 \\
\hline \multirow[t]{2}{*}{ Bagi Hasil } & 0,061 & 0,090 & 0,072 & 0,674 & 0,503 \\
\hline & 0,256 & 0,052 & 0,513 & 4,193 & 0,000 \\
\hline
\end{tabular}

a. Dependent Variabel: Proses Keputusan

1. Lokasi berpengaruh secara signifikan terhadap proses keputusan nasabah menabung.

2. Bagi hasil tidak berpengaruh secara signifikan terhadap proses keputusan nasabah menabung.

3. Promosi berpengaruh secara signifikan terhadap proses keputusan nasabah menabung. 


\section{h. Uji Koefisien R}

Tabel 15. Uji Koefisien R

\begin{tabular}{|l|c|c|c|c|c|}
\hline Model & $\mathrm{R}$ & R Square & $\begin{array}{c}\text { Adjusted R } \\
\text { Square }\end{array}$ & $\begin{array}{c}\text { Std. Error of } \\
\text { the Estimate }\end{array}$ & $\begin{array}{c}\text { Durbin- } \\
\text { Watson }\end{array}$ \\
\hline $\mathrm{l}$ & $0,734^{\mathrm{a}}$ & 0,539 & 0,519 & 1,213 & 2,289 \\
\hline
\end{tabular}

a. Predictors: (Constant), Promosi, Lokasi, Bagi Hasil

b. Dependent Variabel: Proses Keputusan

Berdasarkan tabel di atas, menunjukkan nilai Adjusted $\mathrm{R}$ Square sebesar 0,519. Hal ini menunjukkan bahwa variabel lokasi, bagi hasil dan promosi hanya dapat menjelaskan 51,9\% variansi variabel keputusan nasabah menabung. Sedangkan sisanya, yaitu $48,1 \%(100 \%-51,9 \%)$ ditentukan atauu dijelaskan oleh variabel lain yang tidak termasuk dalam analisis atau penelitian regresi ini.

\section{E. Kesimpulan}

Berdasarkan hasil penelitian tentang pengaruh lokasi, bagi hasil dan promosi terhadap proses keputusan nasabah membuka tabungan flexible di Bank Panin Dubai Syariah Jakarta, maka didapat kesimpulan:

1. Hasil pengujian menunjukkan variabel Lokasi (Xl) tidak berpengaruh secara signifikan terhadap proses keputusan nasabah menabung.

2. Hasil pengujian menunjukkan variabel Bagi Hasil (X2) berpengaruh secara signifikan terhadap proses keputusan nasabah menabung.

3. Hasil pengujian menunjukkan bahwa variabel Promosi (X3) berpengaruh secara signifikan terhadap proses keputusan nasabah menabung.

4. Hasil pengujian di atas menunukkan bahwa nilai $\mathrm{F}$ hitung sebesar 22,642 sedangkan F tabel sebesar 3,72, maka dapat diketahui nilai F hitung 22,642 > F tabel 3,72 dan nilai probabilitas signifikansi 0,000 lebih kecil dari 0,05. Maka dapat dikatakan bahwa variabel Lokasi(X1), Bagi Hasil(X2) dan Promosi(X3) berpengaruh secara simultan terhadap proses keputusan nasabah menjadi nasabah di Bank Panin Dubai Syariah.

\section{Daftar Pustaka}

Abdullah, M. Ma'ruf Manajemen Bisnis Syariah" Aswaja Pressindo, Yogyakarta 2014.

Adiwarman Karim, Bank Islam Analisis Fiqih dan Keuangan (Jakarta: IIIT Indonesia, 2003). 
Ascarya, "Akad \& Produk Bank Syariah" Rajawali Press, Jakarta, 2011.

Burhanudin, "Pasar Modal syariah". Jakarta: UII Press, 2008.

David, F. Strategic Management. Salemba Empat, Jakarta. 2006.

Dewi, Gemala "Aspek-aspek Hukum dalam Perbankan dan Perasuransian Syariah di Indonesia", Kencana Prenada Media Group, Jakarta: Kencana 2005.

Huriyati, Ratih, "Bauran \& loyalitas konsumen”, Bandung: Alfabeta, 2008.

Husein Umar "Studi Kelayakan Bisnis", Jakarta: PT Gramedia Pustaka Utama, Ed. Ke-3. 2001.

Ghozali, Imam "Aplikasi Analisis Multivariate Dengan Program SPSS 19 Edisi V" BP Universitas Diponegoro, Semarang 2011.

Hurriyati, Ratih "Bauran Pemasaran dan Loyalitas Konsumen", Cetakan Kedua. ALFABETA CV. 2008.

Hasan, Zubairi "Undang-Undang Perbankan Syariah Titik Temu Hukum Islam dan Hukum Nasional" Raja Grafindo Persada, Jakarta 2009.

Istijanto. Aplikasi Praktis Riset Pemasaran. Jakarta: PT Gramedia Pustaka Utama. 2009.

Jayadi, Abdullah, "Beberapa Aspek tentang Perbankan Syariah" Mitra Pustaka, Yogyakarta, 2011.

Kasmir, "Dasar-dasar Perbankan", PT Raja Grafindo Persada, Jakarta. 2013.
"Pemasaran Bank", PT Raja Grafindo Persada, Jakarta. 2005.

Kotler \& Keller, "Manajemen Pemasaran". Edisi Kedua Belas Jilid l. PT Indeks, Jakarta 2008.

Lupiyoadi, "Manajemen Pemasaran Jasa Teori dan Praktek", Salemba Empat. Jakarta, 2001.

Muhammad, "Audit \& Pengawasan Syariah pada Bank Syariah Catatan Pengalaman" UII Press, Yogyakarta, 2008.

Muhammad, Rifqi "Akuntansi Keuangan Syariah" P3EI Press, Yogyakarta, 2010.

Mulazid, Ade Sofyan, "Pelaksanaan Sharia Compliance Pada Bank Syariah (Studi Kasus Pada Bank Syariah Mandiri, Jakarta)", Madania, Vol 20, NO.1, Jakarta 2016.

Rochaety, Ety, dkk."Metodologi Penelitian Bisnis dengan Aplikasi SPSS", Jakarta, Mitra Wacana Media, 2009.

Rianto Al Arif, M. Nur "Lembaga Keuangan Syariah Suatu Kajian Teoritis Praktis" CV Pustaka Setia, Bandung 2012.

Saiman, Leonardus, "Kewirausahaan Teori, Praktik, dan Kasus-kasus", Salemba Empat, Jakarta, 2009.

Sunyoto, Danang, "Dasar-Dasar Manajemen Pemasaran", Penerbit CAPS, Yogyakarta, 2012.

Tjiptono, Fandy,"Strategi Pemasaran". Yogyakarta: penerbit andi. 2002. "Model-model Akad Pembiayaan di Bank Syariah (Panduan Teknis Pembuatan Akad/Perjanjian Pembiayaan 
pada Bank Syariah)" UII Press, Tarmizi, Erwandi, "Harta Haram Muamalat Yogyakarta, 2009. Kontemporer" PT Berkat Mulia Insani, Bogor, 2013.

Saefuddin, A. M. 2011. Membumikan Ekonomi Islam. PT. PPA Consultants, Jakarta.

Statistika Perbankan Syariah. 2017.

Taswan. "Manajemen Perbankan: Konsep, Teknik \& Aplikasi". Yogyakarta: UPP STIM YKPN Yogyakarta. 2010.

Sugiyono, Metode Penelitian Kuantitatif Kualitatif dan $R$ \& D CV. Alfabeta Zamir, Iqbal. "Analisis Risiko Perbankan Bandung, 2010. Syariah". Jakarta: Salemba Empat. 2000. 